This item was submitted to Loughborough's Research Repository by the author.

Items in Figshare are protected by copyright, with all rights reserved, unless otherwise indicated.

\title{
Lean production, worker empowerment, and job satisfaction: A qualitative analysis and critique
}

\section{PLEASE CITE THE PUBLISHED VERSION}

https://doi.org/10.1163/156916307X168656

\section{PUBLISHER}

(C) Koninklijke Brill NV, Leiden, Published by Sage

\section{VERSION}

AM (Accepted Manuscript)

\section{PUBLISHER STATEMENT}

This work is made available according to the conditions of the Creative Commons Attribution-NonCommercialNoDerivatives 4.0 International (CC BY-NC-ND 4.0) licence. Full details of this licence are available at: https://creativecommons.org/licenses/by-nc-nd/4.0/

\section{LICENCE}

CC BY-NC-ND 4.0

\section{REPOSITORY RECORD}

Vidal, Matt. 2019. "Lean Production, Worker Empowerment, and Job Satisfaction: A Qualitative Analysis and Critique”. figshare. https://hdl.handle.net/2134/27610. 


\title{
Lean Production, Worker Empowerment, and Job Satisfaction: A Qualitative Analysis and Critique
}

\author{
Matt Vidal $^{1}$ \\ Department of Sociology \\ Center on Wisconsin Strategy \\ 7122 Social Science \\ University of Wisconsin \\ Madison, WI 53706 \\ mvidal@ssc.wisc.edu \\ office: 608-265-5987 \\ fax: 608-262-9046 \\ Forthcoming in Critical Sociology
}

\footnotetext{
${ }^{1}$ The research for this paper was made possible by a grant from the Alfred P. Sloan Foundation for the Advanced Manufacturing Project (AMP) research consortium. This paper is a revision of a presentation given at the $16^{\text {th }}$ Annual Meeting on Socio-Economics, George Washington University, Washington DC, USA, July 8-11, 2004. I would like to thank those who attended the presentation for helpful suggestions, including Glenn Patmore, Ida Regalia, Daphne Taras, and Jelle Visser. Useful feedback on an earlier incarnation of this paper was given by Jennifer Farnham, Michael Handel, Dan Luria, Jamie Peck, Joel Rogers, Rob White, and participants of the Economic Sociology Workshop at the University of WisconsinMadison. Finally, I would like to thank Gary Herrigel, Chip Hunter, Pablo Mitnik, Jeff Rothstein, Josh Whitford, Erik Wright and Jonathan Zeitlin for very detailed and helpful commentary and criticism.
} 


\begin{abstract}
Increased employee involvement in manufacturing is argued to be central to lean production. The alleged increase in the responsibilities and abilities of front-line workers has been labeled empowerment by many commentators. Such empowerment is said to increase job satisfaction. Yet, there is surprisingly little qualitative research directly addressing the relationship between participatory work arrangements and job satisfaction, and the quantitative evidence is much less clear than often presented. Qualitative data presented here show that workers can be satisfied under relatively traditional Fordist arrangements and that increasing employee involvement does not necessarily increase satisfaction. My research highlights the role of individual work orientations in mediating the effects of objective characteristics of job design - such as participatory work arrangements - on job satisfaction. Further, individual preferences for work arrangements are not consistent and invariable, but context-dependent and subject to reevaluation.
\end{abstract}

\title{
Key words
}

Employee involvement, labor process, Fordism, high performance work organization, Taylorism 


\section{Introduction}

The traditional Fordist model of mass production is based on a Taylorist division of labor in which workers' knowledge is systematically collected, operations are simplified into constituent parts and specified in great detail, and front-line workers are rigidly supervised and expected to complete their tasks with no deviation or input into the process (see, e.g., Braverman 1974: Ch. 5; Friedman 1977: 91-96). Increased use of socalled participatory work practices, or employee involvement (EI), is seen by many as a defining factor of post-Fordist industrial restructuring in the US and other advanced capitalist economies. Within manufacturing, increased EI through practices such as teamwork and continuous improvement is argued to be central to lean production and other forms of "high performance" work organization.

The increase in the responsibilities and abilities of front-line workers - labeled empowerment by many academics, business gurus and practitioners - is argued to increase job satisfaction, primarily through increasing the intrinsic rewards of work. In the more extreme formulations "the project of liberated, fulfilling work, originally interpreted as an anti-capitalist project" is now "likely to be staged by capitalist management itself” (Kern and Schumann 1992: 111; quoted in Vallas 1999: 68). Yet, there is surprisingly little qualitative research directly addressing the relationship between participatory work arrangements and job satisfaction, and the quantitative evidence is much less clear than often presented. ${ }^{2}$ I argue that the relationship between worker

\footnotetext{
2 There is a large qualitative literature on worker experience with post-Fordist work arrangements in manufacturing (Barker 1993; Garrahan and Stewart 1992; Graham 1995; Grenier 1988; Milkman 1997; Rinehart et al. 1997; Smith 2001; Thomas 1989; Vallas 2003a; Vallas 2003b). These studies, however, do not systematically address the relationship between participatory arrangements and job satisfaction,
} 
empowerment and job satisfaction is much more complex than suggested by what seems to be the standard view among the advocates of lean production and high performance work organization. Much of the work on the effects of EI is based on a stylized fact that assumes that workers were unmotivated and dissatisfied under Fordism and that motivation and satisfaction - and hence performance - improve as EI increases.

Based on interviews in nine manufacturing plants, I show that workers can be motivated and relatively satisfied under more-or-less traditional Fordist arrangements and that increasing EI does not necessarily lead to increased satisfaction. To the extent that EI involves substantial new responsibilities it may also bring pressures and psychological tensions that are experienced as burdens rather than challenges, potentially swamping any direct effect of participation on job satisfaction. Individual orientations toward work play in important role in mediating the effects of objective characteristics of job design - such as participatory work arrangements - on job satisfaction. Further, individual preferences for work arrangements are not consistent and invariable, but context-dependent and subject to reevaluation.

\section{Theory and prior research on participation and job satisfaction}

The empowerment theory of job satisfaction

focusing instead on the distance between managerial rhetoric and reality, the extent to which participatory arrangements increase managerial control or allow workers to negotiate outcomes, and/or what conditions limit or increase the effectiveness of new participatory arrangements. There is a parallel literature (discussed below) directly examining the relationship between participatory arrangements and job satisfaction that has overwhelmingly been based on survey data. 
In contradistinction to traditional Taylorism, argues MacDuffie, a lean production system requires that "workers must have both a conceptual grasp of the production process and the analytical skills to identify the root cause of problems" so that they may "identify and resolve problems as they appear on the line” (1995a: 201; see also 1995b). This requires decentralization of problem-solving and decision-making responsibilities along with “extensive” off and on the job training; in short, the reintegration of conception and execution. ${ }^{3}$ MacDuffie contends that while motivation was low under mass production it must be high under lean production so that workers will apply their skill and knowledge through “discretionary effort.” Furthermore, “workers will only contribute their discretionary effort to problem-solving if they believe their individual interests are aligned with those of the company, and that the company will make a reciprocal investment in their well-being” (1995a: 201). Both of these arguments are made primarily by assertion and do not seem well grounded in empirical research. ${ }^{4}$

\footnotetext{
${ }^{3}$ Generally, management initiates workplace restructuring to improve flexibility, achieve better process control, and reduce "waste" and other costs. I show in detail elsewhere (Vidal Forthcoming) that work systems may achieve these goals, becoming lean enough for management, with minimal expansion of the new “cognitive role” for workers (cf. MacDuffie 1995b).

${ }^{4}$ In more recent work with collaborators, MacDuffie's position has been modified somewhat in response to the observation of widespread reticence or overt resistance to job enrichment initiatives (Hunter et al. 2002). They suggest that union workers may resist changes when they perceive that such changes will reduce benefits won through collective bargaining, and that such resistance may be overcome through a variety of contextual mechanisms such as strong union backing of reforms and the perception that such reforms will improve job security by making the plant more competitive. This is a welcome effort to examine employee reactions though it does not alter the main assumptions regarding motivation and satisfaction that underlie the empowerment theory.
} 
A similar model of satisfaction and motivation can be found in the high performance model of Appelbaum and collaborators, who argue that "The core of a highperformance work system (HPWS) in manufacturing ... is that work is organized to permit front-line workers to participate in decisions that alter organizational routines” (2000: 7). The HPWS model shares with lean an explicit theory of job motivation and satisfaction. In addition to the opportunity to participate and policies to guarantee adequate skills, the third requirement of an HPWS is proper incentives: "The purpose of work reform and participation is to elicit effort from employees that does not normally result from monitoring and adherence to stated job descriptions and formal responsibilities [i.e., from traditional Taylorism]. How can an organization motivate employees to use their imagination, creativity, enthusiasm, and intimate knowledge of their particular jobs for the benefit of the organization” (2000: 42)? They discuss three mechanisms: financial incentives such as gainsharing; the building of mutual trust; and intrinsic incentives.

Appelbaum et al. argue that "HPWSs will increase the intrinsic rewards of work and thereby enhance satisfaction and commitment” (2000: 42). Similarly, Cappelli et al. contend that new work arrangements "rely heavily on transferring decision-making to individual employees - empowerment - and on using teams as substitutes for management structures ... [A]s the behavioral research has suggested for decades, employees like the greater autonomy and variety associated with these new work systems and seem to respond with better performance” (1997: 8). ${ }^{5}$ Cappelli et al. assert in

\footnotetext{
${ }^{5}$ Whether teamwork decentralizes decision-making authority, increases autonomy or, more generally, benefits workers is an empirical question. Bélanger et al. have recently shown one set of relatively unique
} 
numerous places (pp. 11, 57, 200, 206) that employees like new participatory arrangements more and that they improve employee attitudes. Finally, MacDuffie argues that workers in lean production have new cognitive and social roles and that "there is considerable evidence that workers in lean production plants respond favorably to these expanded roles. Particularly noteworthy is that workers with prior experience in traditional mass production plants typically say they never want to go back to that setting” (1995b: 61, my emphasis; see also Adler 1995).

MacDuffie, Appelbaum and collaborators do not simply argue that the supposed intrinsic rewards of empowerment are sufficient in all cases to increase motivation and discretionary effort. MacDuffie does argue that motivation is best increased by multiple incentives from integrated and overlapping bundles of HR and manufacturing practices, generating both intrinsic and extrinsic rewards (1995a: 200). Similarly, Appelbaum et al. argue that financial rewards and trust are important mechanisms in generating discretionary effort. Nonetheless, both invoke what appears to be a standard empowerment theory of job satisfaction based on the conventional, yet oversimplified assumptions that under mass production workers are required to expend manual but not mental effort, and manual effort is induced effectively through monitoring despite low

conditions under which teamwork may increase autonomy and benefit workers, cautioning that "there is only a small group of cases where it does so” (2003: 249). Others argue that through peer pressure and strict self-discipline, teamwork serves to maintain hierarchical authority without bureaucratic control (Barker 1993; Graham 1995; Grenier 1988; Smith 2001: 166; cf. Vallas 1999). 
motivation and satisfaction ${ }^{6}$; while under lean production and HPWO workers are required to expend both manual and mental effort, and a key mechanism inducing discretionary effort is the intrinsic rewards of job enrichment and employee involvement. Like the earlier job characteristics model of Hackman and Oldham (1980), work under lean production and HPWO is argued to be highly intrinsically rewarding, thus simultaneously generating increased motivation and satisfaction. However, the empirical literature on participation and satisfaction is not as clear and supportive as some advocates of worker empowerment suggest.

\section{Prior research on participation and satisfaction}

Of the voluminous literature on job satisfaction, the meta-analyses of Cotton and collaborators are perhaps the most often cited to support claims of positive effects of EI (Cotton 1993; Cotton et al. 1988). The strength and robustness of these findings, however, has been called into question. Leana et al. find "little support for Cotton and his collaborators’ conclusions regarding the effects of participative decision-making” (1990). In his own meta-analytic reanalysis of Cotton et al.’s data, Wagner finds that "support is provided for the conclusion that research has produced evidence of statistically significant but small relationships between participation and performance or satisfaction and that it has failed to verify the presence of strong, large relationships. Evidence from

\footnotetext{
${ }^{6}$ Particular forms of Fordist work organization may be quite boring or arduous, and traditional Fordist work on an auto assembly line in particular may be extremely regimented. My argument is simply that there is heterogeneity within Fordist work and variability in individual work orientations, that Taylorism is a contested and often incompletely-realized tendency, and that certain aspects of Fordist work (e.g., buffers) may be highly desirable for some workers.
} 
the findings of 10 other reviews of participation research upholds the same conclusion” (Wagner 1994: 327). Wagner concludes that "though statistically significant, the average effects revealed in [the meta-analysis] are so small as to raise questions about practical significance” (p1994: 325). This seems to be the exactly the case with Appelbaum et al.'s findings regarding job satisfaction. They find a statistically significant, positive relationship between the opportunity to participate (OTP) and job satisfaction in the steel industry, but the coefficient of the OTP scale is a practically insignificant 0.002 and the relationship loses statistical significance when trust and intrinsic rewards added to the model (2000: Table 9.6A). By way of comparison, their more fully specified regression model of job satisfaction finds a significant, positive relationship with perceptions of fairness in pay, which has a coefficient of 0.138 (2000: Table 9.6B). Appelbaum and collaborators find no relationship between the OTP and job satisfaction in the apparel and medical electronic instruments industries.

On a careful reading of the research on participation, the dominant picture that emerges is one of contradictory findings and lack of support for a strong, consistent effect of OTP on job satisfaction. Even the widely-cited Cotton et al. analysis finds a positive relationship with satisfaction only for informal participation and employee ownership. There is either mixed or no evidence for a relationship with four other forms of participation: direct participation in work decisions, consultative participation, short-term participation and representative participation. Yet, the attempts of Cotton et al. to add nuance to our understanding by focusing on the differential effects of different forms or participation seem to have been lost on many, particularly lean production advocates who largely speak in general terms about the positive effects of "new arrangements" and 
“expanded roles.”

Until recently, moreover, the level of participation has not been considered in quantitative analyses. Godard finds that the level of involvement in various participatory practices "generally has a number of positive implications for employees up to a point, though it also results in more stressful work. Beyond that point, any positive effects of further adoption tend to decline in magnitude and in some cases may even become negative, while work becomes even more stressful” (2001: 791).

Over the period of 1989 to 1998, Handel finds a significant increase in desire for intrinsic rewards, concluding that this "supports the view that workers increasingly seek intrinsic rather than material rewards, despite the long-run stagnation in earnings and growth in earnings inequality” (2003: 25). However, given that there is no change in the percentage that report that high income is "very important" and a $16 \%$ increase in percentage reporting that job security is "very important," it would be more accurate to say that more workers increasingly seek intrinsic rewards "in addition to" - not "rather than” - material rewards. Perhaps more important, it is unclear whether these measures of intrinsic rewards - “interesting work” and “independent work” - are actually measuring changes in practice that go under the rubric of lean production or HPWO.

\section{Hypotheses from the standard view}

In the conventional view workers are induced to expend discretionary under lean production largely because of the intrinsic rewards of job enrichment and EI. In this view job satisfaction (and motivation) is largely a function of job objective characteristics. Yet the findings in the quantitative empirical literature have been contradictory and 
inconsistent, and even statistically significant correlations are usually of very small magnitudes. This suggests a need for qualitative research to investigate these relationships more deeply. To orient the qualitative analysis, I draw on Miller and Monge’s (1986) distinction between three models of the effects of participative practices on individual performance. In the cognitive model, participation "enhances the flow and use of important information” (1986: 730). Because workers have in many cases better information about their jobs they will be able to make better decisions. In the affective model, participation satisfies higher-order psychological needs, leading to greater satisfaction and motivation, and hence better performance. Finally, contingency models suggest that "participation will affect satisfaction and productivity differently for different people and situations” (1986: 731).

The empowerment theory of job satisfaction of MacDuffie, Appelbaum et al., and others combines affective and cognitive models of the effects of participation. In contrast to the contingency model, the standard empowerment theory yields very strong expectations: workers have stable preferences for particular types of work arrangements; motivation and satisfaction will be low under Fordist arrangements; the latter will be experienced as much less interesting, challenging and/or autonomous than work under lean production and HPWO; workers will enthusiastically embrace participative arrangements because of increased intrinsic rewards; given a choice between Fordist arrangements and lean or HPWO, workers will clearly chose the latter; and these various evaluations and reactions will be relatively consistent across individual workers.

\section{Data and method}


The present analysis is based on data from nine firms reporting that they have made significant attempts to implement principles and practices associated with lean production or HPWO. In total, 55 people were interviewed including 39 workers, 13 managers and 3 union business representatives. The interviews were in-depth, semi-structured and openended and I was given a plant tour in every plant visited. The management interviews ranged from one-and-a-half to over three hours total (a few in multiple interviews) and the worker interviews ranged from half an hour to one hour. Managers in each firm were asked to make available for interview on company time four to six workers.

Four of the firms are non-union, four have union representation and one is a firm with an Employee Stock Ownership Plan (ESOP). Six of them are mainly small to medium sized suppliers to large original equipment manufactures (OEMs) such as John Deere and Electrolux Home Products. One is a small supplier of hydraulic systems to other manufacturers, while another is a small firm selling OEM products to industrial markets. A final plant is part of a larger, vertically integrated firm; it does some external supplying and also sells OEM products to distributors for the consumer market. Six of the nine are primarily in the metal fabrication and machining industries, one is wholly in plastics and two firms manufacture and assemble items with plastic and various fabrics. Firms were located and approached either through contacts at manufacturing associations $^{7}$ or cold calling based on LexisNexis Business database searches. All are located in the US Midwestern state of Wisconsin.

\footnotetext{
${ }^{7}$ Associations used for contacts include the Wisconsin Manufacturing Extension Partnership, the Wisconsin Regional Training Partnership, and the Jobs with a Future partnership.
} 
Of course, neither the sample of employees nor employers are representative in the statistical sense. It is possible that the firms, and perhaps even more likely the workers I interviewed are anomalous in one or more regards. While these concerns must be kept in mind I have no reason to believe that the workers and managers I spoke with are atypical or exceptional vis-à-vis some mythical average employee in an average firm. The firms I visited were all maintaining or growing business (apart from one who recently lost around $\$ 40$ billion in metal fabrication business as a key customer outsourced to China); many were considered strategic suppliers by key OEM customers. In terms of individuals, in each firm a range of opinions and attitudes is represented workers supporting, opposing, and neutral to recent changes. While these workers (and plants) are not statistically representative, the in-depth, open-ended interviews offer two advantages: the ability to explore and find themes salient to the interviewees and the opportunity to more thoroughly probe understandings and experiences on these and other themes.

\section{Motivation and effort at work}

“Depends on the person ...”

The conventional view suggests that motivation and effort are largely a function of job design. There are many ways to get at these issues when talking with workers. I always asked a straightforward question of whether new practices affected effort levels. Surprisingly, workers often had to pause before answering this question and some were 
entirely unable to answer the question. One worker who thought that the work cells ${ }^{8}$ had improved overall plant performance offered a typical answer: ““'I don't know about amount of effort. I think it's raised the quality level, you know, by going to one-piece flow ... That's a hard one to say ... [T]here's people out there that really work hard and there's people that just kind of, you know, they just kind of flow along.” Or in the words of a worker from another plant: “No, they haven’t ... you still have people standing around and you still have people that are busting their butt.”

These comments are illustrative for two reasons. First, though increased stress seems to be a relatively common complaint, these quotes suggest that lean practices may not be aimed primarily at enlisting workers in speedup, as many critics have charged. While this may be the case elsewhere - particularly in the context of an assembly line in auto plants (Berggren 1992; Graham 1995; Lewchuk and Robertson 1997) - my interviews almost universally failed to reveal any widespread perception of work intensification under lean production. ${ }^{9}$ Second, these quotes express a common understanding among both workers and managers that motivation and effort are primarily a function of individual attitudes.

\footnotetext{
${ }^{8}$ Lean production emphasizes "continuous flow” of work (rather than batch production), organized either through assembly lines or product-focused work areas usually referred to in the US as “cells” or "cellular production,” and elsewhere as “U-shaped lines” (Japan), “flow groups” (Scandinavia) or "production islands” (Germany) (Hyer and Wemmerlöv 2002).

${ }^{9}$ Indeed, work intensification is theoretically limited by the lean goal of no-defect production, as Dohse et al. observe (1985), though US managers in the auto industry are known for stressing output over quality, even in ostensibly lean settings where workers are supposed to be able stop the line (Milkman 1997; Rothstein 2005).
} 
Another way to get at these issues is to ask about employee reactions to workplace changes. The union Shop Chair in the hydraulic systems plant explained his observation from years on the floor: "Now you've got about 10 percent of the people that will get involved, okay? You've got 80 percent that will just sit and wait, and you've got 10 percent that it doesn’t make any difference what you did, they won't do anything." The general distribution, if not the specific percentages, echoes comments by other workers and managers that when it comes to workplace change, including "lean transformations,” most people are somewhere in the middle, cautious and reserved, with a few naysayers and a few enthusiasts in the tails. The key point to take here is that the perceptions I found on the shop floor are much different than the claims of lean advocates, which suggest a skewed distribution where the mode is very close to the "enthusiastic" tail of the distribution, in sharp contrast to the symmetric distribution widely perceived by the workers and managers I spoke with.

Another worker elaborates a bit on the theme that the individual source of variation may be more important than objective job characteristics. He suggests not only that some workers may be satisfied in a traditional Taylorist job but that they may be motivated to do good quality work without having a desire for more "challenging” work.

I think it still depends on the person and their attitude, that's the biggest thing ... Where they come from, how long they've been here. A lot of times you see guys that have been here for a long time, they're used to doing things one way, they don't want to change, and it's hard for them to learn something new. A lot of these guys ... want to sit in their chair and wait for the part to come to them, do whatever they've got to do to it, put it back on the line ... they get into that ... [N]othing wrong with that, but it's hard for that person to 
change and learn something new if they've got that kind of attitude where they really don’t want to learn nothing. [T] hey still want to do a quality job, but they don’t feel like they should have to learn anything new.

"I always thought we were a high performance work organization"

As the previous quote suggested, the Fordist side of the stylized fact underlying the standard view of motivation and satisfaction - in which the latter are universally low under the former - may be eliding important real-world complexities. Indeed, the standard view would seem to suggest that craft pride had all but become extinct under the monolith of Fordism. Yet, a craft pride evident among much of the workforce predates any of the so-called high-performance changes at a small shop I visited, composed of mostly skilled machinists with a long average tenure in the workforce and a relatively active union rank-and-file. As in all of the other union shops with long-tenured workforces that I visited (three of the four), the union members often voiced suspicion at management's motives and suggested that the work quality had always been a focus of the union, sometimes despite management's output-oriented decisions. One worker explains how this craft pride exists no matter how management tries to organize the work:

Well, I always thought we were a high performance work organization. You know? I mean ... you can throw a bunch of names out there ... it might make you more efficient, but does it really change what you do? I mean does it really change ... what you're about? If you're a good solid employee, it shouldn’t change you one way or another. 
Another worker from the same shop expresses a similar sentiment, this time clearly articulating the craft pride of a skilled machinist. When asked about whether the cells, teams and committees had changed motivation or satisfaction on the floor, he replied:

maybe a little bit. We've always been a pretty proud group of what we do ... when we produce a part, we know it's a good part, we move it on down the line. We do it once; we do it right. That kind of attitude is all the way through the shop ... [W]e always had a good base attitude as far as taking care of the customer.

Another misleading aspect of the conventional wisdom on motivation and satisfaction is that there were no mentally engaging or challenging aspects of work in a Fordist labor process. While this was certainly the Taylorist ideal, as Lewchuk and Robertson note "Careful studies of mass production facilities have shown that managerial control of decision-making was never total ... efficient production required workers to exercise individual discretion in the face of unexpected problems and gaps in the planning process” (1997: 37). Similarly, I find that traditionally organized work may be perceived as mentally engaging and challenging. Here a press operator describes the difference between “pick-and-place” presses, where parts must be fed individually into the machine, and presses with progressive dies that run continuously with coils of sheet metal. Note that he is actively challenging himself to give his best performance, in part creating an engaging environment. 
[I]f it's a pick-and-place, then you have to move the parts and, you know, you'll have to work the job ... You have to watch the job ... because something could happen to the machine ... I like running pick-and-place usually ... Well ... I like the progressive because that's a lot more challenging ... There's a lot more to learn on progressive jobs. Where pick-and-place ... I like challenging myself to see if I can make the rate or how fast I can go. ... Where once you're running progressive ... some of the jobs you're just watching the parts, you know watching everything go, and that can be boring. But setting up, definitely the challenge in progressive is a lot better.

This worker pursues a strategy of making work interesting by challenging himself, voluntarily exerting considerable effort. Other workers will expend somewhere between the minimum and maximum amount of effort, depending on their strategic orientation toward work (Hodson 1991). As one worker reveals, “I just ... work at a steady pace and ... after awhile ... kind of calculate, ‘Do I have enough? Oh, I’m doing good!’ I mean I don't, I'm not one of those that say, 'Okay, 58 is my rate, that's all I'm doing.' ... [I]f I can make it, I make it.” She works hard, but not too hard. And as she notes, there are others who will work just hard enough. They think to themselves “'Hundred percent. I hit rate. Okay, I’ve got 20 minutes. Nope ... no more ... They’re not paying me more.’” These two workers suggests a continuum of behavioral types of worker, with those working just hard enough at one end, and at the other end, those challenging themselves by working full steam ahead. It's not clear if the motivation of either of the polar types, or those in the middle would be affected by job enrichment and increased opportunity to participate. Furthermore, as the discussion of different types of presses indicated, traditionally organized jobs may be perceived as challenging and, perhaps, 
challenging enough. In the next section I present more examples of traditionally organized jobs being perceived as interesting or as providing more autonomy than work under lean production.

\section{Job satisfaction: a moving target}

"I had a routine ..."

I now question more directly the job characteristics-satisfaction link of the standard view. For MacDuffie the empowerment process starts with the opportunity to gain a broad conceptual knowledge of the overall production process, so that one may understand the relation of a particular operation to those up and downstream in the process. In practice this often begins with job rotation and cross training, which are argued to increase intrinsic rewards and hence job motivation/satisfaction in contrast to the monotony of being responsible only for the same operation, over and over again. Yet, in contrast to MacDuffie (1995b) and Adler (1995) I found many workers who prefer the traditional arrangements and express little desire for something more "empowering." For example, one worker who had experience with both a leaner fabrication department, organized into cells running small lots, and a more traditional stamping department running large batches, states

Actually I like running the same machine. I mean, just walking into the job and start running. Where you, some of the other jobs, if you're not used to running them you've got to figure out the ins and outs in a lot of them ... Most of the jobs I've got on that big press I can usually jump right on and get it going right away. 
This worker did express that there is some benefit to variety, though as he notes, not all traditionally organized jobs are uninteresting and boring: “I’m doing several different things. Even though I'm running on the press ... I’m filling baskets, I'm changing dies. Where for a person on the line that's just welding all day long, then you probably want [job] rotation.” Yet this worker had little interest in those aspects that are supposed to increase intrinsic rewards (rather than simply reduce monotony) - the actual process of learning new tasks and skills, gaining a greater understanding of the overall production process. His motivation was in doing one thing and doing it well, in becoming an expert in a particular operation.

The plant just discussed, which has cellularized lean production in one area and Fordist batch production in another, provides an interesting opportunity for some workers to experience lean production and have the possibility of transferring back into a more traditional Fordist environment. A short time after they implemented cells, which included tube bending and assembly operations, one worker I talked with transferred back to the Fordist side, noting that he wanted to go back "because over there you do a lot of jumping around. And I'd like to know exactly where I'm going to be from one day to the next.” Other workers also expressed preferences for the predictability associated with more traditional arrangements. This worker, moreover, experienced his Fordist job as more autonomous than the work in the cells: “Well, like in the press department, I'm running my own press. Everything’s organized the way I want it ... [in the cells] you're going from one spot to the next, I mean you really don’t know.” Both critics (Berggren 1992) and advocates have also noted how the extreme regimentation and visibility of lean production restrict individual autonomy more than Fordist arrangements, though 
advocates suggest that this loss may be offset by an increase in "democratic Taylorism" (Adler 1995) or “collective autonomy” (Klein 1989). Yet this worker - like others I spoke with - had experience with the kaizen process but would rather not be involved, preferring instead the predictably and individual autonomy of traditional work.

For some workers job satisfaction is much more tied to an individualized notion along the lines of 'a fair day’s work for a fair day’s pay,' rather than to any possibility of expanding one’s role in problem-solving and decision-making. Indeed, depending on one’s work orientation, even traditional rote assembly positions may be experienced as positively satisfactory relative to jobs with more responsibility:

I’m happy with it ... I've always told myself that if I can come in and do my job and like what I'm doing, and not take it home, that's the kind of person I am ... I don't want a higher-level job where I'd have stress that I would have to take home. For me it's, what's outside of work, you know. You've got to love your job too, but I mean I’m happy to leave it here and then just be able to go home and, you know, I have three kids ....

There are also many, perhaps more workers who do prefer the opportunity to participate, precisely because they have always had ideas to contribute. As another worker notes, referring to worker involvement in a continuous improvement committee, "it actually did a lot of good ... [A]ctually, I could have told them the answers ten years ago, but nobody wanted to listen. But now that things got so bad, it was either listen or we're going under.” This was a common refrain in the union shops I visited, as indicated by a worker from the union machine shop: "These are the fellows that are working with this stuff for a long time ... They've always had ... really good input, it's just a matter of 
having people listen to that input.” Thus, some workers don't want to participate in decision-making while others have always wanted to give their input. Neither of these cases corresponds neatly with the assumptions of the empowerment theory.

Amorphous preferences and adaptability

As with the larger literature on job satisfaction, the discussion thus far may have given the impression that workers have well-formed and stable preferences regarding work arrangements. But there are good reasons to question this stability, as suggested by the work of March and Simon (1993), Hackman and Oldham (1980), and more recently, Easterlin (1996) and Handel (2003). Workers may redefine what is 'acceptable' and change their evaluation of given situations, for example, with the passage of time or as appraisals of alternatives change.

An astute first-line supervisor described how he observed just such a process. With the implementation of cells and job rotation "There was a bit of a struggle when we first ... initiated it. You know, pretty much the consensus was, 'Hey, I’m good at doing this job. Let me just do this job. I don't want to do that job.' But now, they're getting used to it. It breaks up the day for them, and it's easier on the body.” As the quote indicates, many workers were originally content with their Taylorist jobs; the biggest complaint has to do with the new "enriched" jobs, with workers responding "I only had to do this one job before and now I have to do multiple jobs.” While they initially resisted the change, their evaluation of broadened job responsibilities is transformed as they adapt to these new conditions. Perhaps most workers become relatively more satisfied now that things are "mixed up for them." 
While they may come to like the new participatory arrangements, this is a slow process of adaptation to new circumstances rather than a one of workers enthusiastically embracing new arrangements as the standard view suggests. Contrasting traditional with more participatory and lean arrangements, one worker was self-aware of this process: "I guess [I'm satisfied] about the same, now that I'm used to it. You know, the change thing is always difficult to get used to doing it that way ... One day you're running 10 to 20 parts, and it's down to one and three or four ... It's just the thing of getting used to it. You adapt.” In many cases there does not appear to be a desire for a broadened work responsibilities and a broader understanding of the overall process. Yet the fact that workers can adapt to these new circumstances suggests that there may not have been well-formed preferences in the first place - it may be that expressed satisfaction with more traditional arrangements is also due, at least in part, to adaptation. Indeed, if questions of job satisfaction are probed further one can find very complex and sometimes even contradictory feelings. An example comes from a worker who identifies himself as a welder, despite now rotating on a regular basis between all operations in the cell. He begins by noting how he likes the cells and job rotation much better. Our exchange began as follows:

And so how do you like the new cells then compared to the lines?

A lot better. A lot better.

Do you do just welding? Do you do any job rotation?

Yeah, I do the rotation. I do every part there ... Everybody gets a chance. They do the whole system ... So that's not bad.

So you like that better? 
Yeah. Oh, yeah.

It kind of breaks things up.

Breaks it up, gets you to stand up a little bit and sit down a little bit, you know. Otherwise ten hours standing up is hard on your legs.

But when pushed a little further he expresses that while he may be more satisfied with the job rotation he doesn't think that it is the best way to organize the work from an efficiency standpoint:

Oh, well I think if they kept the welders just doing the welding, I think it would be better .... I think it would run a lot smoother that way ... But the rotation, then you've got this guy here trying to figure out which way this and that there, so you just lost about five, you know, and then he gets all mad at you

He was thus a bit more satisfied with the task variety of the job rotation despite feeling that it may slightly hinder performance.

When first asked whether his overall job satisfaction has increased or decreased as a result of the recent changes, he replied without hesitation that it has increased. But when asked to elaborate why, specifics do not readily come to mind and his attention focuses on interpersonal relations rather than specific job characteristics, despite just having answered a battery of detailed questions about changes in job content: "Well I just, I think change, different foremen, different people, you know, just everything.” Upon further probing, and further reflection by the worker, more complex, ambiguous and even confused feelings emerge: 
Well, I've been here for, like I said ... 10 years. When I started here, it was a really nice place to work for ... I mean it was really nice. And now it's like ... I think they spend more money over the budget, you know, where they should work with the people and stuff. Right now they, you know, you just go out there and do what you've got to do and people don't have that attitude anymore. I mean if you've been here so long, you know, you're here, you work, you do your job and stuff like that. Now you've got, like if you're all caught up on your machine or something and if you're going to get a piece of gum or whatever out the machine, they don't bother you. And now if you do that, it's like holy cow! But I don't know, it’s just - it gets better if you, you know, it goes both ways.

This response seems to indicate that it used to be a nicer place to work, contradicting his earlier statement that his satisfaction has increased. He appears to want, like many workers I interviewed, to express a number of specific dissatisfactions. But he is saddled with truly contradictory feelings. Whatever specific complaints he may have, he also understands that, in his own words, “you just go out there and do what you've got to do.” That is, it's his job and whatever else he may dislike about it, so long as the interpersonal relations and management are decent he'll make the best of it. He continues: "I think [management is] doing the best they can ... it's better than they did for a long time, you know. They're not bad to work with. They're easy to get along with.” Like other workers this one expressed many specific gripes about various aspects of the work organization but answered that he is happy in general. This indicates that job satisfaction is a multidimensional concept and perhaps more can be learned from investigating the specific dimensions rather than attempting to gauge a single, summary 
measure. Answering that one is relatively satisfied, it seems, may be a rather habitual response.

\section{Employee involvement: increased responsibilities}

The empirical analysis has focused thus far mostly on worker responses to more traditional positions. But what happens when workers actually get into so-called empowered positions? Do they enthusiastically embrace the new responsibilities and opportunities of enriched jobs. In the previous section I suggested that workers may adapt, adjusting their standards, values and evaluations so that they become relatively satisfied. Yet another alternative is possible: the outcome of increased responsibilities and new, more demanding routines may be frustration and stress that can have an adverse affect on job satisfaction.

\section{Frustration and stress}

For MacDuffie the core of a lean or flexible production system is that the ability to deal with contingencies is transferred from the system to the workers. Through the removal of buffers the interdependent labor process heightens vulnerabilities to expose problems, and workers are supposed to solve these problems through continuous improvement, or kaizen. Significant and widespread change, however, may be more anxiety-arousing than incremental changes, which are easier to adjust to. In one of the plants that has done perhaps the most systematic restructuring of all of the plants I visited, worker frustration and stress were high. One worker who excelled under the individual piece rate system ended up taking a very large pay cut under the new system of cells and gainsharing. 
While this clearly affected his evaluation of other changes in significant ways, his story is illustrative also of how increased involvement and responsibilities can increase frustration and stress.

[When] you don’t have a part, you’ve got five people standing around not doing anything. The way we had it before was individual piecework, so when you ran out of a part there, you only had one guy out of a job. You could transfer one guy to a different area where he could help out and fill in. We have that no longer ... Now, so they're going through [kaizen] events and setting up these areas ... It's sad. I see a good company ... was in business for 85 years, something like that. It was a productive company, prosperous company. And I don’t see it ... you run out of one part, you shut down a whole area.

The problems with the new payment system were clearly a significant source of this workers' discontent. However, he also articulates a common complaint about the fragility of lean production; rather than seize the opportunity to participate in problem-solving, he preferred not to have such responsibilities. This is precisely the situation that workers are supposed to embrace as intellectually challenging. From the perspective of some workers, management by stress (Parker and Slaughter 1995) - where the bufferless production system is kept under constant stress to expose weak spots and impose discipline - seems a much more apt characterization of this labor process than empowerment.

In fact, some workers prefer forecast-driven, buffered production, rather than the “challenges” and opportunities for problem-solving in an interdependent, fragile lean system. Here is the response of one worker in a different plant to what have been the 
main effects of the transition to just-in-time (JIT) inventory control and other associated changes on his daily routine:

Everyday it seems like you're looking for parts, you know, if there’s a job or you don't run enough ... Before you'd run, let's say you run 500 pieces, they actually only needed 400. So you've got 100 to play with or something like that ... [N]ow with the smaller batches you don’t have that many of those to play with. I guess there's no room for error ... You can’t - can’t screw any up; we need them all. So, that's the big problem.

For lean advocates perhaps the core of empowerment is worker participation in kaizen - the ability to participate in decision-making and problem-solving. Yet such allegedly intrinsically rewarding work is not universally desired, as indicated by the response of one worker: “they're always changing things around here. I don't get on this side that often. It's a jungle, I don't like it on [this] side.” The side which he disliked was an area of customer-dedicated cells which were the oldest ones in the plant. At the time of my visit they were on their fourth round of restructuring the cells to improve the work flow with a high amount of worker participation. That is, this side of the plant appears to be a well-functioning example of the core ideal of lean production, continuous improvement in work flow to reduce “waste.” This worker had 25 years tenure and chose to be a jeep driver rather than use his seniority to post into the "jungle" of continuous improvement. Again, for this worker the opportunity to participate appears to have negative effects on stress that swamped any positive direct effects on satisfaction.

An uneasy paradox: resisting empowerment 
There is one empirical puzzle that the empowerment theory of job satisfaction simply cannot explain, which is that workers often resist the transformation to a highinvolvement system. This was the case in three of the four union plants I visited, where serious worker resistance was encountered by management. Only in the one union plant with a very short average tenure of the workforce did management not see significant resistance and in this case they were met with reticence or caution instead of enthusiasm, as one plant manager explains:

It wasn't as much resistance, but [problems with] active participation, I want to say apathy, it might not be the right word, but, just kind of standing around to see what happens. With another program, is it going to go away in a couple of weeks? You know, 'I’m happy doing what I want to do, I don’t want to do any more than that.' So, you know, we work around them.

In an IAM $^{10}$ plant that had active support for the high performance work organization initiatives from both the regional union business agent and the IAM HPWO Department, the manager estimates that $70 \%$ of the workforce resisted the changes at first and a full year after they started he's still thinks 30 to $40 \%$ are resisting. These high levels of initial resistance stemmed largely from a long-tenured, organized workforce jaded by a history of aborted managerial attempts at restructuring. He discusses how

\footnotetext{
${ }^{10}$ International Association of Machinists and Aerospace Workers, AFL-CIO.
} 
We have to do work differently than we have in the past ... The days of paying for us to stand there and watch a friggin' machine run are over ... This ... workforce ... hasn't woken up to that reality yet, even [their] business agent [is] telling them that.

The plant manager also notes that "You need to get a significant quantity of the informal leaders converted over. And if you don't, they're going to fight you. You know, they might even smile and shake their heads yes in meetings, but boy, out on that shop floor they're talking it down.”

\section{The eye of the beholder}

One of the most striking findings from my interviews with workers is the diversity of responses to nearly identical situations. One example is how workers respond to the minimal buffers, smaller lot sizes and quicker changeovers required by the JIT system. Presumably one of the main ways for workers to be engaged in more "thinking” work, and something that should increase the challenge and task variety of the work is quick changeover/setup reduction on presses. Yet, many workers only find this frustrating and prefer buffered production with longer runs, as one worker illustrates:

They've been trying [to reduce inventories], unfortunately, which means we do more changeovers on our stock jobs ... When you run long runs, you set it up once, you get it going good, and it stays in there for 48, 50 hours, you know. You get it fine-tuned; everything gets smooth. If ... you're running for six hours, that's not so bad when it's a six-hour total and there's three hours of setup and three hours of run. You get really frustrated when it's a five-hour setup and there’s only one hour to run. 
Smaller lots and lack of buffers was an extremely common complaint among workers. Yet clearly some people do consider it an interesting challenge. As one worker explains “changeovers are actually good because you don’t look at the clock all day ... What I like about it is it’s like being a mechanic; you work with your hands.” But along with more responsibilities also comes more potential anxiety. As this worker continues to note “it gets frustrating when [the machine starts] chopping and you don’t know why ... I find it challenging until I wear out everything I know how to do and it's still messing up. So I get frustrated. And that's why I have to call my Process Tech over” Still for others these new changes are simply not that salient. Either way, for them, it's just work. In response to a question about changing effort levels and new responsibilities after the press brakes had been incorporated into cells with other operations, one worker expresses this not uncommon refrain:

I guess we have more responsibility - I don’t know if it’s more. Not really I don’t think. Just the normal routine. ... Either you run the brake or you run [machines in] the cell ... I mean the rate's still there no matter what machine you're on ... You're asking them to run three machines versus one, but ... on this one machine if you run it all day, you get 200 pieces done. And if they run all three machines you're only going to get, let's say 75. But you're doing all the machines and it's complete when you're done with it. So I guess you're not really asking for more, it's just that the rate just changed, is kind of what it comes to ... I don't really have that many complaints. Kind of go with the flow. I don't know. Change is good. Try to make it the best you can. 
In addition to has rather unformed opinion of the different arrangements, it is noteworthy that this worker also articulates his reason for being adaptable: either way it's work and he just goes with the flow.

Finally, and more generally it is noteworthy that in my interviews I've given the workers numerous opportunities to express what they like and dislike about their jobs and have prompted them with various different specific questions about job design, decisionmaking, the ability to give input, etc. While a frequent complaint was lack of communication about changes in the plant, almost none of the workers I interviewed voluntarily expressed increased satisfaction specifically with new decision-making or problem-solving responsibilities. After direct questions about their ability to contribute their ideas, many would say they were happy that management would consider their ideas, but on the whole such issues did not seem an important aspect of most workers’ work orientations. Even in the leaner shops, most workers expressed that their main mechanism for input was direct communication with supervisors or through suggestion programs; the opportunity to participate was not a major aspect of their evaluation of other arrangements such as teams and committees. The following exchanges from two different plants illustrate this point:

Now are there ways for - new ways or old ways - for workers to give their input? Things like, you know, suggestion boxes or problem-solving committees?

They do have one here ... like one of the guys come up with a plan to talk to the foreman about it. It's, you know, it's up and down ... So like 50/50. I think they should pay attention more to that. 
Another worker in a different plant:

And so the group meetings maybe are one way for the associates to give their input? Definitely.

Are there other ways?

You can always go in and, any questions, any concerns, you can always go to your group leader, your supervisor ... They've told us many times the door is open ... 'Any time you have any questions, you can come to us and ask.'

When offline teams or committees are mentioned it is usually to note that workers are free to give their input, rather than actually being involved in decision-making or problem-solving:

What do you think have been the main ways for workers to give their input, if any? We have a few meetings. You know they’ve got meetings where you can put your input in. I mean if something gets done or not is another story, but they do let you put your input in.

In general these are not the type of enthusiastic responses one would expect if the employee involvement and the opportunity to participate were significant factors determining work motivation and satisfaction. More often then not, questions about participatory arrangements asked in different ways yielded similar answers - not necessarily indifferent but far from passionate. 


\section{Discussion and conclusion}

Three main themes emerge from my discussions with workers and managers. First, individual orientations toward work appear to be at least as important in determining worker satisfaction as job design. The considerable variability in individual reactions to similar situations suggests a large role for individual work orientations, casting doubt on whether participatory arrangements qua objective situations can effectively motivate or satisfy workers (cf. Hackman and Oldham 1980). Though the opportunity to offer input may be a welcome change from the Taylorist rejection of workers' ideas, the effects of increased opportunities for substantive participation in decision-making and problemsolving depend on individual work orientations. Second, job satisfaction is multifaceted and individual work preferences unstable and context-dependent. Over time, workers may reevaluate work arrangements and adapt to given situations, particularly when they perceive little alternative choice. Third, these data support Kelly's [, 1992] argument that motivation and performance at work do not appear to be closely linked with job satisfaction (see alsoHodson 1991).

The workers I spoke with simply want to do a good job at work, have good interpersonal relations, be treated with dignity, and ultimately make the best out of their situation. I can't say how representative these worker vignettes. While it is possible that these workers may be odd exceptions, my own interpretation is that these are normal people in ordinary workplaces. So what can be made of these findings? First, these data demonstrate that workers may perceive traditionally organized jobs as challenging often challenging enough - and interesting, in certain cases providing more individual 
autonomy than lean practices such as teamwork and continuous improvement, which, with their emphasis on standardization and clearly defined procedures may severely limit individual autonomy.

Second, the experiences of workers, managers and union business representatives that I spoke with all point to a consistent pattern: there appears to be a normal distribution of worker attitudes toward increased employee involvement, where a relatively small proportion of workers are enthusiastic about the opportunity to participate in substantive decision-making and problem-solving, a relatively small proportion are staunchly opposed and the most are somewhere in the middle. For most workers predictability at work, good interpersonal relations, effective communication from management, and job security appear to be more important in providing a positive work context than opportunities for substantive participation in decision-making and problem-solving. Though many workers may adapt to post-Fordist work arrangements, the lack of systemic buffers and the increased responsibilities of lean production were not enthusiastically greeted by most the workers I spoke with, often generating increased stress and frustration.

While the data presented here cannot be used to directly address which arrangements or situations are consistently related to job satisfaction, they do provide insight into the relationship between worker empowerment - the opportunity and ability to participate - and job satisfaction. What is considered intrinsically rewarding varies with individual work orientations. Depending on whether one desires the opportunity to participate, the latter may be experienced as more stressful than rewarding, suggesting the following causal model (Figure 1). The opportunity to participate may be positively 
related to job satisfaction but is also positively related to stress, which is negatively related to job satisfaction. The less one is interested in (and prepared for) empowerment the more likely it is to increase stress and frustration, overwhelming any direct, positive effects of empowerment on job satisfaction. ${ }^{11}$

\section{[FIGURE 1 ABOUT HERE.]}

The data presented above, then, are seriously problematic for the standard (empowerment) theory of job satisfaction. More positively, there are important contributions in the sociology of work that have not been incorporated into debates about lean production and HPWO that can help make sense of my findings. The present analysis is generally supportive of Kalleberg's early multi-dimensional model of job satisfaction, which included a significant role for individual work orientations (1977). In future research it will be important to focus on specific dimensions of job satisfaction and allow for complex and contradictory psychological states, which may not be able to be meaningfully captured by a single composite measure. Parsimony may have to be sacrificed for descriptive accuracy.

Kelly (1992) has persuasively argued for a "twin-track" model, in which satisfaction and motivation/performance have different determinants. This model resonates strongly with my findings. For example, many of the workers interviewed were motivated by craft pride to do what they considered quality work yet were dissatisfied

\footnotetext{
${ }^{11}$ Interest in the opportunity to participate is also partially endogenous to the labor process, but may be treated as exogenous in the short run.
} 
with new arrangements with they perceived as harming quality or customer satisfaction. Some workers were motivated to do quality work but did not desire "challenging" work, while others actively created a more-or-less satisfactory environment in a work context that Hackman and Oldham would likely deem of low motivating potential. These observations are also consistent with Hodson’s (1991) typology of workplace behaviors, which makes nonsense of the empowerment theory of satisfaction. In his terms, "smooth operators” advance their own goals as a first priority and thus are likely to be satisfied, but they may or may not advance organizational goals. In contrast, "good soldiers” are likely to identify with the organization and thus be committed to it, but may be unsatisfied, for example, if they observe less effort on the part of smooth operators.

Similarly, Burawoy (1982; 1987) has shown that workers may regularly expend "discretionary" effort under traditional mass production as they create their own games to counteract boredom or deprivation. These arguments are consistent with my findings, which indicate that worker motivation may be largely independent of whether the labor process is participatory or not and that workers may find their own motivation even under Fordist arrangements. Rather than concentrate exclusively on objective situations, research should focus also on the perceptual malleability of job characteristics; "workers possess the ability to construct their own satisfaction by selectively perceiving and interpreting their social environment and their own past actions" (Salancik and Pfeffer 1978: 249).

In addition to selective perception, an important component of future research on behavioral strategies at work should be a focus on adaptation. As March and Simon argued, "Repeated failure to discover 'acceptable' alternatives leads generally to a 
redefinition of 'acceptable’” (1993: 136). More recently Handel has discussed the readjustment of standards in terms of job satisfaction, invoking the Easterlin paradox or hedonic treadmill: "most people usually compare their situation to current norms, causing average assessments to remain stable despite changing objective conditions” (2003: 33). Or, as Hackman and Oldham have argued, while some people may be dissatisfied in poorly designed or bad jobs, others "gradually adapt to this unsatisfactory state of affairs and accept it is their lot in life;" they adapt to "what they experience as the inevitability of it all” (1980: 22, 17).

Again, these arguments find resonance in my findings, which are similar to those of Freeman and Rogers (1999: 23): While most workers initially respond that they are relatively satisfied with their workplace, further discussion of specific issues often reveals discontent about how workplaces are run. In short, people adapt to given job context, creating situations in with which they are relatively comfortable and satisfied. Such psychological adaptation - in particular adaptation to "the inevitability of it all" - appears to be another way, in addition to the behavioral strategies discussed by Burawoy (1982; 1987) in which consent is generated within the labor process.

The foregoing suggests that quantitative analyses (and predictions) are likely confounded due to three factors, which future theory and research should take into account. First, by definition dispositions, orientations and perceptions vary across individuals. Second, configurations of dispositions, orientations, and perceptions are not static and stable but potentially subject to reflective transformation. Individual disposition may be modified to better fit lived experience and/or cope with a given situation. Whatever specific complaints workers may have, many feel that, in the end, as one 
worker put it, "you just go out there and do what you've got to do.” Finally, a single composite measure of job satisfaction may elide important complexities, glossing over problems with specific dimensions of the work situation as well as active strategies vis-àvis these problems.

Qualitative analysis brings these underlying problems out into the open. This suggests the need for more qualitative research on job satisfaction. Yet methodological problems remain in addition to the problem of generalizability. A key problem in this regard will be designing research to deal with problems of comparing evaluations of different situations (including past and present), given unstable, interdependent, adaptable and context-dependent preferences. 


\section{References}

Adler, Paul. 1995. 'Democratic Taylorism': The Toyota Production System at NUMMI. In Steve Babson, ed., Lean Work: Empowerment and Exploitation in the Global Auto Industry. Detroit: Wayne State University Press.

Appelbaum, Eileen, Thomas Bailey, Peter Berg, and Arne Kalleberg. 2000.

Manufacturing Advantage. Ithaca: Cornell University Press.

Barker, James R. 1993. “Tightening the Iron Cage: Concertive Control in Self-Managing Teams.” Administrative Science Quarterly 38:408-437.

Bélanger, Jacques, Paul K. Edwards, and Martyn Wright. 2003. “Commitment at Work and Independence from Management: A Study of Advanced Teamwork.” Work and Occupations 30:234-252.

Berggren, Christian. 1992. Alternatives to Lean Production: Work Organization in the Swedish Auto Industry. Ithaca, NY: Cornell University Press.

Braverman, Harry. 1974. Labor and Monopoly Capital: The Degradation of Work in the Twentieth Century. New York: Monthly Review Press.

Burawoy, Michael. 1982. Manufacturing Consent: Changes in the Labor Process under Monopoly Capitalism. Chicago: University of Chicago Press.

Burawoy, Michael. 1987. The Politics of Production. New York: Verso.

Cappelli, Peter, Laurie Bassi, Harry Katz, David Knoke, Paul Osterman, and Michael Useem. 1997. Change at Work. Oxford: Oxford University Press.

Cotton, John L. 1993. Employee Involvement: Methods for Improving Performance and Work Attitudes. London: SAGE. 
Cotton, John L., David A. Vollrath, Kirk L. Froggatt, and Mark L. Lengnick-Hall. 1988. “Employee Participation: Diverse Forms and Different Outcomes.” Academy of Management Review 13:8-22.

Dohse, Knuth, Ulrich Jugens, and Thomas Malsch. 1985. “From 'Fordism' to 'Toyotism'? The Social Organization of the Labor Process in the Japanese Automobile Industry.” Politics and Society 14:115-145.

Easterlin, Richard A. 1996. Does Satisfying Material Needs Increase Human Happiness? In Richard A. Easterlin, ed., Growth Triumphant. Ann Arbor, MI: University of Michigan Press.

Freeman, Richard B. and Joel Rogers. 1999. What Workers Want. Ithaca: Cornell University Press.

Friedman, Andrew L. 1977. Industry and Labour: Class Struggle at Work and Monopoly Capitalism. London: The Macmillan Press Ltd.

Garrahan, Paul and Paul Stewart. 1992. The Nissan Enigma: Flexibility at Work in a Local Economy. London: Mansell.

Godard, John. 2001. "High Performance and The Transformation of Work? The Implications of Alternative Work Practices for the Experience and Outcomes of Work.” Industrial and Labor Relations Review 54:776-805.

Graham, Laurie. 1995. On the Line at Subaru-Isuzu: The Japanese Model and the American Worker. Ithaca, NY: Cornell University Press.

Grenier, Guillermo J. 1988. Inhuman Relations: Quality Circles and Anti-Unionism in American Industry. Philadelphia: Temple University Press. 
Hackman, J. Richard and Greg R. Oldham. 1980. Work Redesign. Reading, MA: Addison-Wesley Publishing Company.

Handel, Michael J. 2003. “Trends in Perceived Job Quality, 1989-1998.” Work and Occupations Forthcoming.

Hodson, Randy. 1991. "Workplace Behaviors: Good Soldiers, Smooth Operators, and Saboteurs.” Work and Occupations 18:271-290.

Hunter, Larry W., John Paul MacDuffie, and Lorna Doucet. 2002. “What Makes Teams Take? Employee Reactions to Work Reforms.” Industrial and Labor Relations Review 55:448-472.

Hyer, Nancy and Urban Wemmerlöv. 2002. Reorganizing the Factory: Competing Through Cellular Manufacturing. Portland, OR: Productivity Press.

Kalleberg, Arne L. 1977. "Work Values and Job Rewards: A Theory of Job Satisfaction.” American Sociological Review 42:124-143.

Kelly, John. 1992. "Does Job Re-Design Theory Explain Job Re-Design Outcomes?” Human Relations 45:753-774.

Kern, Horst and Michael Schumann. 1992. New Concepts of Production in West German Plants. In Paul Adler, ed., Technology and the Future of Work. New York: Oxford University Press.

Klein, Janice A. 1989. “The Human Costs of Manufacturing Reform.” Harvard Business Review :60-66.

Leana, Carrie R., Edwin A. Locke, and David M. Schweiger. 1990. "Fact and Fiction in Analyzing Research on Participative Decision Making: A Critique of Cotton, 
Vollrath, Froggatt, Lengnick-Hall, and Jennings.” The Academy of Management Review 15:137-146.

Lewchuk, Wayne and David Robertson. 1997. "Production Without Empowerment: Work Reorganization from the Perspective of Motor Vehicle Workers.” Capital and Class 63:37-64.

MacDuffie, John Paul. 1995a. “Human Resource Bundles and Manufacturing Performance: Organizational Logic and Flexible Production Systems in the World Auto Industry.” Industrial and Labor Relations Review 48:197-221.

MacDuffie, John Paul. 1995b. Workers' Roles in Lean Production: The Implications for Worker Representation. In Steve Babson, ed., Lean Work: Empowerment and Exploitation in the Global Auto Industry. Detroit: Wayne State University Press. March, James G. and Herbert A. Simon. 1993. Organizations. Cambridge, MA: Blackwell.

Milkman, Ruth. 1997. Farewell to the Factory: Auto Workers in the Late Twentieth Century. Berkeley: University of California Press.

Miller, Kathrine I. and Peter R. Monge. 1986. “Participation, Satisfaction, and Productivity: A Meta-Analytic Review.” The Academy of Management Journal 29:727-753.

Parker, Mike and Jane Slaughter. 1995. Unions and Management by Stress. In Steve Babson, ed., Lean Work: Empowerment and Exploitation in the Global Auto Industry. Detroit: Wayne State University Press. 
Rinehart, James, Christopher Huxley, and David Robertson. 1997. Just Another Car Factory? Lean Production and Its Discontents. Ithaca, NY: Cornell University Press.

Rothstein, Jeffrey S. 2005. 'Driven to Compete: Workers, Unions, and General Motors' Global Manufacturing System in Mexico and Wisconsin', PhD Thesis Thesis, Sociology, University of Wisconsin, Madison.

Salancik, Gerald R. and Jeffrey Pfeffer. 1978. “A Social Information Processing Approach to Job Attitudes and Task Design.” Administrative Science Quarterly 23:224-253.

Smith, Vicki. 2001. Crossing the Great Divide: Worker Risk and Opportunity in the New Economy. Ithaca, NY: Cornell University Press.

Thomas, Robert J. 1989. "Participation and Control: A Shopfloor Perspective on Employee Participation.” Research in the Sociology of Organizations 7:117-144.

Vallas, Steven P. 1999. "Rethinking Post-Fordism: The Meaning of Workplace Flexibility.” Sociological Theory 17:68-101.

Vallas, Steven P. 2003a. “The Adventures of Managerial Hegemony: Teamwork, Ideology, and Worker Resistance.” Social Problems 50:204-225.

Vallas, Steven P. 2003b. "Why Teamwork Fails: Obstacles to Workplace Change in Four Manufacturing Plants.” American Sociological Review 68:223-250.

Vidal, Matt. Forthcoming. "Manufacturing Empowerment? 'Employee Involvement' in the Labor Process after Fordism.” Socio-Economic Review .

Wagner, John A. 1994. "Participation's Effects on Performance and Satisfaction: A Reconsideration of the Evidence.” Academy of Management Review 19:312-330. 
Figure 1. Relationship between participation in decision-making and problemsolving and job satisfaction

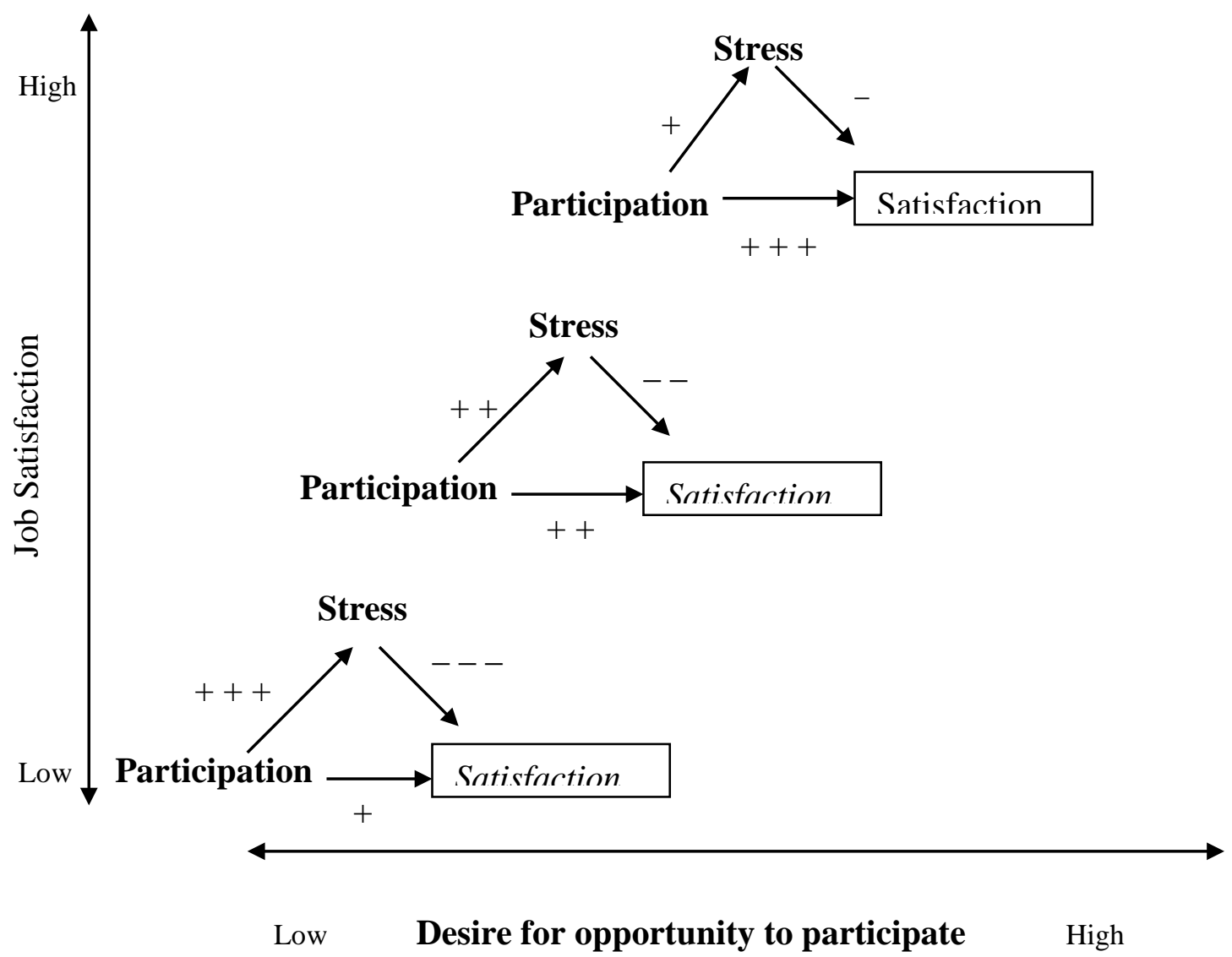

Note: Arrows represent causal relations; plus and minus signs represent direction and strength of relations. Where desire for opportunity to participate is low, negative effects of participation on stress outweigh positive effects of participation on satisfaction. 